\title{
Antiserum to Recombinant Virus Coat Protein Detects Rupestris stem pitting associated virus in Grapevines
}

\author{
Baozhong Meng, Department of Plant Pathology, Cornell University, New York State Agricultural Experiment Sta- \\ tion, Geneva 14456-0462; Rino Credi, Istituto di Patologia Vegetale, Università degli Studi di bologna, Bologna, \\ Italy; Natasa Petrovic, National Institute of Biology, Vecna pot 111, 1000 Ljubljana, Slovenia; Irma Tomazic, Bio- \\ technical Faculty, University of Ljubljana, Jamnikaljeva 101, 1000 Ljubljana, Slovenia; and Dennis Gonsalves, \\ Department of Plant Pathology, Cornell University, New York State Agricultural Experiment Station, Geneva \\ $14456-0462$
}

\begin{abstract}
Meng, B., Credi, R., Petrovic, N., Tomazic, I., and Gonsalves, D. 2003. Antiserum to recombinant virus coat protein detects Rupestris stem pitting associated virus in grapevine. Plant Dis. $87: 515-522$

Rupestris stem pitting (RSP) is the most widespread virus disease of grapevines. The genome of Rupestris stem pitting associated virus (RSPaV), the putative causal agent of RSP, was recently sequenced. Until recently, the only method to diagnose RSP was biological indexing on woody indicator plants, a process that takes 2 to 3 years to complete. This study reports on the production of a polyclonal antiserum to a recombinant coat protein of RSPaV. The antiserum was used effectively to detect RSPaV from various genotypes and tissues of grapevines by Western blot and indirect enzyme-linked immunosorbent assay. Virus antigens were consistently detected in the cambium of dormant canes and in actively growing leaves of grapevines. Moreover, plants of Vitis rupestris 'St. George', the standard biological indicator for RSP, tested positive for RSPaV. The serological methods developed in this study are advantageous as compared with biological indexing because they are more rapid, less expensive, as reliable, and more suitable for assays of a large number of samples.
\end{abstract}

Rupestris stem pitting (RSP) is the most widespread virus disease of grapevines $(6,7,11,16)$. As a component of the Rugose wood (RW) disease complex, RSP elicits pits and grooves on the woody cylinder of the grapevine indicator Vitis rupestris 'St. George' after graft-inoculation (5). Other diseases of the RW complex are LN 33 stem grooving (LNSG), Kober 5BB stem grooving (KSG), and Grapevine corky bark (11). RSP is presumed to be a virus disease based on the fact that the causal organism is transmissible through grafting and that filamentous virus particles have been observed by electron microscopy of grapevines showing symptoms of RSP (28) or of a combination of RSP and LNSG (20). The latter is another disease of the RW complex of grapevines that induces grooves on the stem of the grapevine indicator 'LN 33' ('Couderc' $1613 \times$ 'Thompson Seedless') after graftinoculation (11). However, the relationship between the observed virus particles and RSP has not been established.

Corresponding author: Dennis Gonsalves

E-mail: dgonsalves@pbarc.ars.usda.gov

Accepted for publication 4 November 2002.

Publication no. D-2003-0227-03R

(C) 2003 The American Phytopathological Society
The etiology of RSP is not fully understood. High molecular weight doublestranded RNA (dsRNA) has been associated consistently with $\operatorname{RSP}(1,14,16,17,30)$. Sequence analysis of cDNA clones derived from this dsRNA revealed a genome of a putative RNA virus, which was previously designated Rupestris stem pitting associated virus-1 (RSPaV-1) (14,17). Zhang et al. (31) also reported the genome sequence of a virus isolate from grapevines with RSP in California and named the virus Grapevine rupestris stem pitting associated virus. $\mathrm{RSPaV}$ is considered a member of the newly erected virus genus Foveavirus (12) based on resemblance of the genome structure to the prototype of this genus, Apple stem pitting virus.

Diagnosis of RSP is difficult. The standard procedure is to graft-inoculate the grapevine biological indicator 'St. George' and to watch for symptoms of RSP on the woody cylinder of the indicator plants $(5,11)$. This procedure takes 2 to 3 years to complete, and interpretation of results is sometimes subjective. Reverse transcription-polymerase chain reaction (RT-PCR) assay was recently developed for detection of RSPaV (16,31). Assays of a large number of plants showing symptoms of RSP using specific primers have provided further evidence that RSPaV is the causal agent of RSP $(16,22,31)$. The RT-PCR assay significantly improved diagnosis of
RSP because it is more rapid, more sensitive, as reliable, and less expensive when compared with biological indexing (16). More recently, a simplified procedure was developed for isolation of total RNAs from grapevines and was successfully used with the RT-PCR assay for detection of RSPaV (27).

In spite of the recent development of the nucleic acid-based assays for detecting plant viruses, serological assays are, in general, still the methods of choice for screening large numbers of plant materials for viruses (2). For example, RT-PCR requires an expensive thermocycler and welltrained personnel, while molecular hybridization methods require use of radioisotopes. However, unlike other viruses of grapevines such as Grapevine fanleaf virus and Grapevine leafroll associated viruses, antibodies to RSPaV were not available because the virus had not been isolated. Determination of the genome sequence of RSPaV (17) enabled development and expression of a recombinant coat protein (CP) of RSPaV in bacteria. This, in turn, enabled production of antibodies to the expressed fusion protein.

The objectives of this study were: (i) to produce antibodies to a recombinant $\mathrm{CP}$ of $\mathrm{RSPaV}$, and (ii) to explore use of the antibodies for detecting the virus in different grapevine tissues by Western blot and enzyme-linked immunosorbent assay (ELISA). Furthermore, we recently used the antibodies to visualize the virus particles associated with RSP (23). After preliminary results of this work were presented in the 13th Meeting of the International Council for the Study of Viruses and Virus-like Diseases of the Grapevine (13,15), Minafra et al. (19) also reported the development of an antiserum to a recombinant $\mathrm{CP}$ of RSPaV.

\section{MATERIALS AND METHODS}

Plant materials. Among the 39 grapevine accessions tested for RSPaV, nine French-American hybrids and Vitis riparia 'Grande Glabre' were obtained from the USDA Plant Genetic Resources Unit (PGRU) at Geneva, NY; 30 accessions of $V$. vinifera were obtained from Università degli Studi di Bologna, Italy, or from the 
National Institute of Biology in Slovenia (Table 1). All but 12 of the accessions were biologically indexed for RSP (Table 1). In addition, 29 mother plants of the biological indicator $V$. rupestris 'St. George' were tained from the USDA-PGRU at Geneva, and 15 from the Centre for Plant Health, Canadian Food Inspection Agency, British Columbia (Table 2).

Production of recombinant $\mathrm{CP}$ of RSPaV and antiserum. DNA fragments containing the full-length $\mathrm{CP}$ of $\mathrm{RSPaV}$ were obtained by PCR from the cDNA clone RSP140 (17) with primers 17 and 18 tested for RSPaV, of which 14 were ob-

(Table 3), and ligated into the EcoRI and HindIII sites of the protein expression vector pMAL-c2 (New England BioLabs, Beverly, MA). Escherichia coli XL 1-Blue cells were transformed with the ligate using the heat shock method (26). Bacterial colonies containing the recombinant plasmids were screened. Recombinant plasmids were identified by restriction digestion analysis, and confirmed by DNA sequencing with primer 15 (Table 3). A recombinant protein comprising the $\mathrm{CP}$ of $\mathrm{RSPaV}$, and the maltose binding protein (MBP) was produced in E. coli cells and purified using affinity chromatography

Table 1. Comparison of Western blot ${ }^{\mathrm{a}}$, indirect ELISA, $\mathrm{RT}^{\mathrm{a}} \mathrm{PCR}^{\mathrm{b}}$, and biological indexing ${ }^{\mathrm{c}}$ for detection of Rupestris stem pitting associated virus (RSPaV) in grapevines

\begin{tabular}{lcccc}
\hline Grapevine accessions & & & & Biological \\
indexing
\end{tabular}

a Western blot and indirect enzyme-linked immunosorbent assays were conducted using the antiserum As7-276 produced to a recombinant coat protein of RSPaV to test for RSPaV from leaves or dormant stem cambium tissue of grapevines. For each grapevine accession, four to six leaves of actively growing plants or four to six cuttings of dormant canes were used to obtain the extract.

${ }^{\mathrm{b}}$ Reverse transcription-polymerase chain reaction assays were conducted using double-stranded RNA isolated from cambium tissue of three to six dormant cuttings of each grapevine accession as templates using procedure described by Meng et al. (16). Primers 13 and 14 were used in the RTPCR assays.

${ }^{\mathrm{c}}$ Biological indexing was carried out previously by graft-inoculation of the grapevine indicator plants Vitis rupestris 'St. George'.

${ }^{d}+=$ presence of the expected protein band that reacted with the antiserum As7-276 by Western blot assays or having $\mathrm{OD}_{405}$ values equal to or higher than 2.9 times that of the negative control Vitis vinifera 'Dolcetto' DOLC 69H in ELISA; - = absence of the expected protein bands by Western blot assays or having $\mathrm{OD}_{405}$ values lower than 2.9 times that of the negative control V. vinifera 'Dolcetto' DOLC 69H in ELISA; NT = not tested. according to the manufacturer's manual (New England BioLabs).

Four hundred micrograms of the purified recombinant protein was suspended in 0.5 $\mathrm{ml}$ of column buffer ( $20 \mathrm{mM}$ Tris- $\mathrm{Cl}, 200$ $\mathrm{mM} \mathrm{NaCl}$, and $1 \mathrm{mM}$ EDTA, $\mathrm{pH}$ 7.4), emulsified with an equal amount of Freud's complete adjuvant, and injected subcutaneously into a New Zealand rabbit. Two additional injections of $100 \mu \mathrm{g}$ each were administered 3 and 5 weeks later. Test bleeds were taken immediately before and 2 weeks after the final injection. The final bleed was collected 4 weeks after the final injection. The antiserum was designated As7-276.

Western blot. Four to six petioles or leaf laminas of actively growing grapevine plants, or 0.1 to $0.5 \mathrm{~g}$ of cambium tissue obtained from dormant canes after peeling off the outer layer of bark tissue, were ground to a fine powder in liquid nitrogen and homogenized by grinding in 5 vol or more of extraction buffer $(200 \mathrm{mM}$ Tris$\mathrm{Cl}, \mathrm{pH} 8.2,140 \mathrm{mM} \mathrm{NaCl}$, and $500 \mathrm{mM}$ polyvinylpyrrolidone [PVP]-40). The protease inhibitor phenylmethyl-sulfonylfluoride and $\beta$-mercapto-ethanol (2-Me) were added to the extraction buffer immediately before processing of samples to final concentrations of $1 \mathrm{mM}$ and $10 \mathrm{mM}$, respectively. Tissue extract was centrifuged for $5 \mathrm{~min}$ at $6,000 \times g$, mixed with an equal amount of loading buffer $(62.5 \mathrm{mM}$ Tris$\mathrm{Cl}, \mathrm{pH} 6.8,10 \%$ glycerol, $2 \%$ sodium dodecyl sulfate [SDS], 5\% 2-Me, and $0.05 \%$ bromophenol blue), denatured in boiling water for $5 \mathrm{~min}$, and proteins separated on 5 to $12 \%$ SDS-polyacrylamide gel using a mini-protean II gel apparatus (BioRad, Hercules, CA). Protein bands were visualized with staining solution (45\% methanol, $10 \%$ acetic acid, $45 \%$ distilled water, and 0.25\% Coomassie Brilliant Blue R-250). For Western blotting, protein bands were electro-transferred to polyvinylidene fluoride membranes (Millipore Corporation, Bedford, MA) for $1 \mathrm{~h}$ at $100 \mathrm{~V}$. All steps were conducted at room temperature unless otherwise specified. Membranes were blocked for 45 min with $1 \times$ PBS $(0.8 \% \mathrm{NaCl}, 0.02 \%$ $\mathrm{KH}_{2} \mathrm{PO}_{4}, \quad 0.29 \% \quad \mathrm{Na}_{2} \mathrm{HPO}_{4} \cdot 12 \mathrm{H}_{2} \mathrm{O}$, and $0.02 \% \mathrm{KCl}$ ) containing $2 \%$ Tween-20 and $10 \%$ nonfat dry milk, incubated at $4^{\circ} \mathrm{C}$ overnight with $1: 500,1: 1,500$, or $1: 5,000$ dilutions of As7-276. The membranes were washed with $1 \times$ PBS containing $2 \%$ Tween-20 for 5 min each of 4 times, and then incubated with $1: 5,000$ or $1: 10,000$ dilutions of donkey anti-rabbit IgG/horseradish peroxidase conjugate (AmershamPharmacia, Piscataway, NJ) for $2 \mathrm{~h}$. Membranes were then incubated with $5 \mathrm{ml}$ of SuperSignal chemiluminescence substrate (Pierce Chemical Company, Rockford, IL), and protein bands were exposed to X-ray films.

To test the sensitivity of the Western blot using As7-276, cambium samples from dormant cuttings of 'St. George' C1-2-10 
(Table 2) infected with RSPaV were extracted with 5,50 , and $100 \mathrm{ml} / \mathrm{g}$ of the extraction buffer and tested with As7-276 diluted at 1:500, 1:1,500, and 1:5,000. To compare effectiveness of the Western blot assay with other assays for detection of RSPaV, 39 grapevine accessions of different genotypes and origins were tested by Western blot and RT-PCR. The infection status of the grapevines was previously determined by biological indexing on 'St. George' indicators (Table 1) $(3,16,17)$.

Indirect ELISA. Tests were first conducted to determine the sensitivity of As7276 for detection of the isolated recombinant $\mathrm{CP}$ of RSPaV by indirect ELISA. As7-276 was serially diluted twofold from $1: 250$ to $1: 8,000$ and tested against different amounts of the recombinant protein.

Four to six buds, leaves, or 0.1 to $0.5 \mathrm{~g}$ of cambium tissues from canes were ground to a fine powder in liquid nitrogen and homogenized in 10 vol of extraction buffer as described for the Western blot procedure. After centrifugation at $6,000 \times$ $g$ for $5 \mathrm{~min}, 100 \mu \mathrm{l}$ of the plant extract was placed into duplicate wells of polystyrene microtiter plates (Dynex Technology, Chantilly, VA) and incubated at $4{ }^{\circ} \mathrm{C}$ overnight. Plates were washed with PBS containing 0.05\% Tween-20 (PBST), blocked with $1.5 \%$ bovine serum albumin for $1 \mathrm{~h}$, and incubated with crude or purified As7276 each of a series of dilutions at $30^{\circ} \mathrm{C}$ for $3 \mathrm{~h}$. Purified antibodies were obtained through affinity chromatography on a Protein A Sepharose CL-4B Lab Pack (Amersham-Pharmacia) according to the manufacturer's instructions. Goat anti-rabbit IgG/alkaline phosphotase conjugate (Sigma Chemical Co., St. Louis, MO) was added at a 1:10,000 dilution and the plates incubated at $30^{\circ} \mathrm{C}$ for $2.5 \mathrm{~h}$. One hundred microliters of the substrate $p$-nitrophenyl phosphate (Sigma) at $1 \mathrm{mg} / \mathrm{ml}$ was added to each well. The $\mathrm{OD}_{405}$ values, taken on a Spectra Reader (SLT-Labinstuments $\mathrm{GmbH}$, Grödig, Austria) at 15, 30, 60, 90, and 120 min intervals, were adjusted using the $\mathrm{OD}_{405}$ value of wells containing buffer alone. Ratios of the adjusted OD values of $\mathrm{RSPaV}$-infected tissue versus $\mathrm{RSPaV}$-free tissue of $V$. vinifera 'Dolcetto' DOLC69H or $V$. rupestris 'St. George' plants $(\mathrm{I} / \mathrm{H})$ were calculated. A positive threshold was set at an $\mathrm{I} / \mathrm{H}$ value of 2.9 .

To test effectiveness of As7-276 at detecting $\mathrm{RSPaV}$ in grapevines, tissuecultured plantlets or cambium tissue from dormant canes of nine RSPaV-infected grapevine accessions were tested in Slovenia with either crude or purified As7-276, both at a dilution of 1:1,500 (Table 4). To test if diluting the crude antiserum alone might lower background interference sufficiently to avoid the need of purifying the antiserum, experiments were conducted at Geneva, NY, where seven RSPaV-infected and one RSPaV-free grapevine accessions were tested using crude antiserum diluted at $1: 1,500,1: 3,000$, or 1:5,000 (Table 5). Additional assays were conducted to validate the potential utilization of indirect ELISA as a routine method to diagnose RSPaV. Thirty-nine samples previously tested for RSPaV by RT-PCR, Western blot, and indicator indexing were tested in this study by indirect ELISA.

Table 2. Comparative results of RT-PCR ${ }^{\mathrm{a}}$ and Western blot ${ }^{\mathrm{b}}$ to detect Rupestris stem pitting associated virus (RSPaV) in the indicator Vitis rupestris 'St. George'

\begin{tabular}{|c|c|c|c|c|}
\hline \multirow[b]{2}{*}{ Plant accession } & \multicolumn{2}{|c|}{ RT-PCR } & \multirow[b]{2}{*}{ Western blot } & \multirow[b]{2}{*}{ Source } \\
\hline & Primers 13\&14 & Primers 21\&22 & & \\
\hline C1-2-03 & $t^{\mathrm{c}}$ & + & + & United States $^{\mathrm{d}}$ \\
\hline C1-2-06 & + & + & + & United States \\
\hline C1-2-09 & + & + & + & United States \\
\hline C1-2-10 & + & + & + & United States \\
\hline C1-2-11 & + & + & + & United States \\
\hline C1-2-13 & + & + & + & United States \\
\hline C1-2-18 & + & + & + & United States \\
\hline C1-2-19 & + & + & + & United States \\
\hline C1-2-22 & + & + & + & United States \\
\hline C1-2-30 & + & + & + & United States \\
\hline C1-2-05 & - & - & - & United States \\
\hline C1-2-08 & - & - & - & United States \\
\hline C1-2-12 & - & - & - & United States \\
\hline C1-2-29 & - & - & - & United States \\
\hline SG990-1A1 & + & + & NT & Canada $^{\mathrm{e}}$ \\
\hline SG990-1A2 & + & + & NT & Canada \\
\hline SG990-1A3 & + & + & NT & Canada \\
\hline SG990-1A4 & + & + & NT & Canada \\
\hline SG990-1A5 & + & + & NT & Canada \\
\hline SG990-1A6 & + & + & NT & Canada \\
\hline SG990-1A7 & + & + & NT & Canada \\
\hline SG990-1A9 & + & + & NT & Canada \\
\hline SG990-1A11 & + & + & NT & Canada \\
\hline SG990-1A12 & + & + & NT & Canada \\
\hline SG990-1A13 & + & + & NT & Canada \\
\hline SG990-1A22 & + & + & NT & Canada \\
\hline SG990-1A32 & + & NT & NT & Canada \\
\hline SG990-1A8 & - & - & NT & Canada \\
\hline SG990-1A10 & - & - & NT & Canada \\
\hline
\end{tabular}

${ }^{a}$ Reverse transcription-polymerase chain reaction was carried out using double-stranded RNA preparations isolated from cambium tissue of three to six dormant grapevine cuttings as templates. Primers used were 13 and 14 derived from the replicase gene and 21 and 22 derived from the coat protein gene of RSPaV.

${ }^{b}$ Western blot assays were conducted using the antiserum As7-276 produced to a recombinant coat protein of RSPaV to test for RSPaV in extracts from cambium tissue of four to six dormant grapevine cuttings.

${ }^{c}+=$ presence of an expected DNA product by RT-PCR or a protein band that reacted with the antiserum As7-276 by Western blot assays; $-=$ absence of expected DNA products by RT-PCR or of the expected protein bands by Western blot assays; NT = not tested.

${ }^{d}$ Samples were from the USDA-Plant Genetic Resources Unit at Geneva, NY.

e Samples were from the Centre for Plant Health, Canadian Food Inspection Agency, British Columbia, Canada.

Table 3. Primers ${ }^{\mathrm{a}}$ used to develop a protein expression vector for production of a recombinant coat protein of Rupestris stem pitting associated virus $(\mathrm{RSPaV})$ and for RT-PCR ${ }^{\mathrm{b}}$

\begin{tabular}{llcl}
\hline Primer & Orientation & Genome position & Sequence $\left(\mathbf{5}^{\prime}\right.$ to $\left.\mathbf{3}^{\prime}\right)$ \\
\hline 9 & Sense & $6244-6260$ & GGCCAAGGTTCAGTTTG \\
10 & Antisense & $6741-6725$ & ACACCTGCTGTGAAAGC \\
13 & Sense & $4373-4392$ & GATGAGGTCCAGTTGTTCC \\
14 & Antisense & $4711-4692$ & ATCCAAAGGACCTTTGACC \\
15 & Antisense & $8423-8405$ & GAGGCGATATTAGCAACCA \\
17 & Sense & $7771-7780$ & TCAGAATTCATGGCAAGTC \\
18 & Antisense & $8569-8551$ & CGTCGAAGCTTGTCGCTGACTTCGTCATCC $^{c}$ \\
21 & Sense & $7917-7936$ & GAGGATTATAGAGAATGCAC \\
22 & Antisense & $8357-8338$ & GCACTCTCATCTGTGACTCC \\
\hline
\end{tabular}

${ }^{a}$ Sequences of the primers were from the genome of RSPaV-1 (17).

${ }^{\mathrm{b}}$ Reverse transcription-polymerase chain reaction.

${ }^{c}$ Underlined sequences contain recognition sites of the restriction enzymes EcoRI (in primer 17) and HindIII (in primer 18) used for construction of protein expression vector pM/RSPaV.CP-2. 
were used (Table 3). These primers were designed to detect a wide array of sequence variants of RSPaV (18).

Seasonal fluctuation of RSPaV antigen levels in grapevine leaves. To test if $\mathrm{RSPaV}$ antigen levels varied with time, four fully expanded leaves were collected from vines of RSPaV-infected plants of the French-American hybrid accessions 'Seyval' or 'Bertille Seyve' 5563 at biweekly intervals from June to October in 1998, and tested for RSPaV by Western blot assays using methods described above. To test the variation in levels of $\mathrm{RSPaV}$ among grapevine accessions, leaf samples of seven RSPaV-infected accessions were collected on 23 October from field plots and tested by Western blot. The accessions assayed included 'Colobel 257', 'Grande Glabre', 'Ravat' 34, 'Seyve Villard' 3160, 'Seyve Villard' 14-287, 'Bertille Seyve' 3408, and 'Lambrusco' LS3.
Detection of RSPaV in 'St. George' indicators. Twenty-nine plants of the indicator 'St. George' were obtained from the USDA-PGRU at Geneva and from the Centre for Plant Health in British Columbia and tested by RT-PCR or by both RTPCR and Western blot. RT-PCR tests were done using primers 13 and 14, and 21 and 22.

Assays of grapevine seedlings for RSPaV. Leaf and cambium tissue were collected from seedlings of 19 grapevine accessions growing in the field and tested for RSPaV by Western blot analysis. These seedlings include Vitis acerifolia accessions 588448 a, 588448 b, and 588449 a; $V$. cinerea accessions 588446 a, 588446 b, and $588460 \mathrm{a} ; V$. coignetiae accessions $588451 \mathrm{c}$ and $588451 \mathrm{~g}$; $V$. monticola accessions $588454 \mathrm{~g}$ and $588454 \mathrm{~m}$; V. riparia accessions $588459 \mathrm{~b}, 495622 \mathrm{~d}$, and 495622 e; V. sp. yenshanansis accessions
588421 a, 588421 b, $588421 \mathrm{~d}$, and 588421 $\mathrm{g}$; and $V$. thunbergii accessions $588452 \mathrm{~b}$ and 588452 c. In addition, 226 plants generated from seeds of $\mathrm{RSPaV}$-infected plants of 'Seyval' were tested by indirect ELISA and also by Western blot using the procedures described above.

\section{RESULTS}

Polyclonal antiserum to recombinant CP of RSPaV. Clone pM/RSPaV.CP-2 was sequenced to confirm that it contained the full-length $\mathrm{CP}$ of RSPaV plus $19 \mathrm{bp}$ of the downstream sequence in frame with the $5^{\prime}$ sequence of the MBP gene. Upon induction with isopropyl- $\beta$ - $d$-thiogalactoside (IPTG) at a final concentration of $0.3 \mathrm{mM}, E$. coli cells harboring $\mathrm{pM} / \mathrm{RSPaV} . \mathrm{CP}-2$ produced a polypeptide of $71 \mathrm{kDa}$ (Fig. 1, lanes 3 and 4). This polypeptide was identified as the expected recombinant protein product based on its size ( $43 \mathrm{kDa}$ for MBP plus 28

Table 4. Effect of crude versus purified form of the antiserum As7-276 to Rupestris stem pitting associated virus (RSPaV) at detecting the virus from cambium samples of dormant grapevine canes or tissue-cultured plantlets using indirect ELISA ${ }^{\mathrm{a}}$

\begin{tabular}{|c|c|c|c|c|c|c|c|c|c|}
\hline \multirow[b]{3}{*}{ Grapevine accession } & \multirow[b]{3}{*}{ RT-PCR $^{\mathbf{b}}$} & \multicolumn{4}{|c|}{ Cambium samples of dormant cane } & \multicolumn{4}{|c|}{ Tissue-cultured plantlet } \\
\hline & & \multicolumn{2}{|c|}{ Crude As ${ }^{c}$} & \multicolumn{2}{|c|}{ Purified As } & \multicolumn{2}{|c|}{ Crude As } & \multicolumn{2}{|c|}{ Purified As } \\
\hline & & $\mathrm{OD}_{405}$ & $\mathbf{I} / \mathbf{H}^{\mathbf{d}}$ & $\mathrm{OD}_{405}$ & $\mathbf{I} / \mathbf{H}$ & $\mathrm{OD}_{405}$ & $\mathbf{I} / \mathbf{H}$ & $\mathrm{OD}_{405}$ & $\mathbf{I} / \mathbf{H}$ \\
\hline Refosk 38 VIII/44 & $+^{\mathrm{e}}$ & 1.13 & 1.12 & 0.70 & 7.78 & 0.85 & 1.05 & 0.22 & 3.67 \\
\hline Refosk 20 IV/110 & + & 1.09 & 1.08 & 0.68 & 7.56 & 0.89 & 1.10 & 0.21 & 3.50 \\
\hline Refosk 43 VI/113 & + & 1.01 & 1.00 & 0.67 & 7.44 & 0.99 & 1.22 & 0.21 & 3.50 \\
\hline Refosk 62 XII/110 & + & 1.10 & 1.09 & 0.61 & 6.78 & 1.02 & 1.26 & 0.33 & 5.50 \\
\hline Refosk 55 IX/110 & + & 0.98 & 0.97 & 0.59 & 6.56 & 0.93 & 1.15 & 0.16 & 2.67 \\
\hline Refosk 51 IX/68 & + & 1.09 & 1.08 & 0.46 & 5.11 & 0.89 & 1.10 & 0.31 & 5.17 \\
\hline Refosk 6 II/18 & + & 1.02 & 1.01 & 0.46 & 5.11 & 1.00 & 1.23 & 0.34 & 5.67 \\
\hline Refosk 4 I/90 & + & 0.98 & 0.97 & 0.43 & 4.78 & 0.87 & 1.07 & 0.45 & 7.50 \\
\hline Refosk 13 III/27 & + & 0.97 & 0.96 & 0.42 & 4.67 & 1.03 & 1.27 & 0.44 & 7.33 \\
\hline St. George C1-2-5 & - & 1.01 & 1.00 & 0.09 & 1.00 & NT & & NT & \\
\hline St. George 239 & - & NT & & NT & & 0.81 & 1.00 & 0.06 & 1.00 \\
\hline Buffer & & 0.18 & & 0.11 & & 0.31 & & 0.20 & \\
\hline
\end{tabular}

a Enzyme-linked immunosorbent assay. Values of $\mathrm{OD}_{405}$ were measured $2 \mathrm{~h}$ after adding the substrate $p$-nitrophenyl phosphate and were calibrated using wells containing only buffer.

b Reverse transcription-polymerase chain reaction assays were carried out using double-stranded RNA isolated from cambium tissue of four to six dormant cuttings or tissue-cultured plantlets of grapevines as templates. Primers were 13 and 14 derived from the replicase gene of RSPaV (16).

${ }^{\mathrm{c}}$ As $=$ the polyclonal antiserum As7-276 produced against a recombinant coat protein of RSPaV.

d Plants of Vitis rupestris 'St. George' C1-2-5 growing in the field and 'St. George' 239 obtained from anther-derived somatic embryos, tested negative for RSPaV by Western blot and RT-PCR, were used as negative controls. The I/H (infected/healthy) ratio of test samples was calculated.

$\mathrm{e}+=$ presence of an expected DNA product by RT-PCR; $-=$ absence of an expected DNA product by RT-PCR; and NT $=$ not tested.

Table 5. Effect of antiserum dilutions on detection of Rupestris stem pitting associated virus (RSPaV) antigens by indirect enzyme-linked immunosorbent assay (ELISA)

\begin{tabular}{|c|c|c|c|c|c|c|c|}
\hline \multirow[b]{3}{*}{ Grapevine accession } & \multirow[b]{3}{*}{ Western blot } & \multicolumn{6}{|c|}{ ELISA $^{\mathbf{a}}$} \\
\hline & & \multicolumn{2}{|c|}{$A s^{b} 1: 1,500$} & \multicolumn{2}{|c|}{ As 1:3,000 } & \multicolumn{2}{|c|}{ As 1:5,000 } \\
\hline & & $\mathrm{OD}_{405}$ & $\mathbf{I} / \mathbf{H}^{\mathbf{c}}$ & $\mathrm{OD}_{405}$ & $\mathbf{I} / \mathbf{H}$ & $\mathrm{OD}_{405}$ & $\mathbf{I} / \mathbf{H}$ \\
\hline Grande Glabre & $+^{\mathrm{d}}$ & 0.99 & 3.30 & 0.87 & 3.78 & 0.89 & 4.45 \\
\hline Colobel 257 & + & 0.92 & 3.07 & 0.86 & 3.74 & 0.82 & 4.10 \\
\hline Canino CNO9 & + & 0.77 & 2.57 & 0.77 & 3.35 & 0.84 & 4.20 \\
\hline Bertille Seyve 5563 & + & 0.82 & 2.73 & 0.78 & 3.39 & 0.77 & 3.85 \\
\hline Canino' 15 & + & 0.88 & 2.93 & 0.72 & 3.13 & 0.72 & 3.60 \\
\hline Seyval & + & 0.83 & 2.76 & 0.68 & 2.96 & 0.61 & 3.05 \\
\hline Pagadebit PGD 2 & + & 0.69 & 2.30 & 0.61 & 2.65 & 0.59 & 2.95 \\
\hline Dolcetto DOLC69H ${ }^{\mathrm{b}}$ & - & 0.30 & 1.00 & 0.23 & 1.00 & 0.20 & 1.00 \\
\hline
\end{tabular}

a Readings of $\mathrm{OD}_{405}$ were measured $2 \mathrm{~h}$ after adding the substrate $p$-nitrophenyl phosphate and were calibrated with values of wells containing only buffer.

b As = the polyclonal antiserum As7-276 produced against a recombinant coat protein of RSPaV.

c Plants of Vitis vinifera 'Dolcetto' DOLC69H, tested negative for RSPaV by Western blot and reverse transcription-polymerase chain reaction, were used as the negative control. The $\mathrm{I} / \mathrm{H}$ (infected/healthy) ratios of test samples were calculated based on the $\mathrm{OD}_{405} \mathrm{reading}_{\mathrm{i}}$ of each accession versus those of the negative control plants.

$\mathrm{d}+=$ presence of an expected protein band that reacted with the antiserum As7-276 by Western blot assays; $-=$ absence of the expected protein bands by Western blot assays. 
$\mathrm{kDa}$ for the $\mathrm{CP}$ of $\mathrm{RSPaV}$ [17]) and its reactivity with the antiserum produced against MBP (New England BioLabs) by Western blot (data not shown). After purification by affinity chromatography, a nearly homogeneous preparation of the fusion protein was obtained (Fig. 1, lane 4). Yield of the purified fusion protein was estimated at $12 \mu \mathrm{g} / \mathrm{ml}$ of the bacterial culture. The polyclonal antiserum obtained was labeled As7-276.

Detection of RSPaV by Western blot. For the initial assay using cambium tissue from dormant cuttings of 'St. George' C12-10, antiserum As7-276 diluted at 1:500 and 1:1,500 readily detected a $28-\mathrm{kDa}$ protein, the size of the CP of RSPaV (Fig. 2). However, antiserum diluted at 1:5,000 only detected the CP in samples extracted with 5 vol of the buffer (Fig. 2). To ensure detection of the virus in samples with low virus titer, 1:1,500 dilutions of the antiserum and 1:5 dilutions of the sample extract were used in subsequent assays.

In addition to the $28-\mathrm{kDa} \mathrm{CP}$, two other protein molecules were detected. A smaller protein of $24 \mathrm{kDa}$ was also detected in all samples in which the $28-\mathrm{kDa}$ protein was found (Figs. 2 and 3A). A larger protein of ca. $40 \mathrm{kDa}$ was also observed in stem cambium samples, regardless of the presence or absence of the 28-kDa CP of RSPaV, but not in leaves of grapevines (Figs. 2 and 3).

The RSPaV CP antigen was detected by Western blot in all the tissues tested, including cambium tissue from dormant canes, laminas, and petioles from young or expanded leaves. Results of the Western blot assays matched those of the RT-PCR

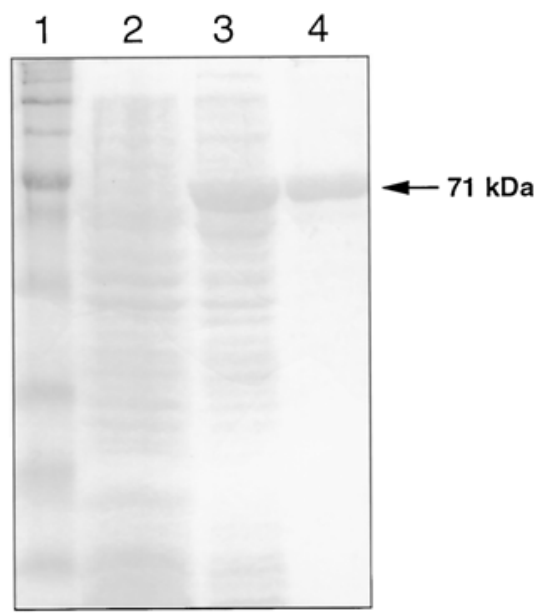

Fig. 1. Sodium dodecyl sulfate-polyacrylamide gel electrophoresis of the recombinant coat protein of Rupestris stem pitting associated virus fused to the maltose binding protein. Lane 1, BenchMark protein ladder; lane 2, crude protein extract of Escherichia coli before isopropyl- $\beta-d$-thiogalactopyra-noside (IPTG) induction; lane 3 , crude protein extract after IPTG induction; lane 4, fusion protein (71 kDa) detected after purification by one-step affinity chromatography using an amylose column. assays (Table 1; Fig. 3). Results of the Western blot and RT-PCR agreed with the indicator indexing of 'St. George' in 24 of the 27 tested accessions (Table 1).

Detection of RSPaV by indirect ELISA. The antiserum As7-276 detected as little as $0.1 \mathrm{ng} / \mathrm{ml}$ of the purified recombinant protein product at all tested dilutions (data not shown).

For testing cambium samples, the negative control was the cambium tissue of 'St. George' C1-2-5. For testing tissue-cultured samples, 'St. George' plants derived from somatic embryos from anthers served as the negative controls. Both sources of 'St. George' plants repeatedly tested negative for RSPaV by Western blot and RT-PCR. To determine the optimal time point for taking the ELISA results, OD values were taken at different intervals after adding the substrate to the wells and were calibrated using OD of wells containing buffer only. Taking OD readings after $2 \mathrm{~h}$ was the optimal time for detection of $\mathrm{RSPaV}$.

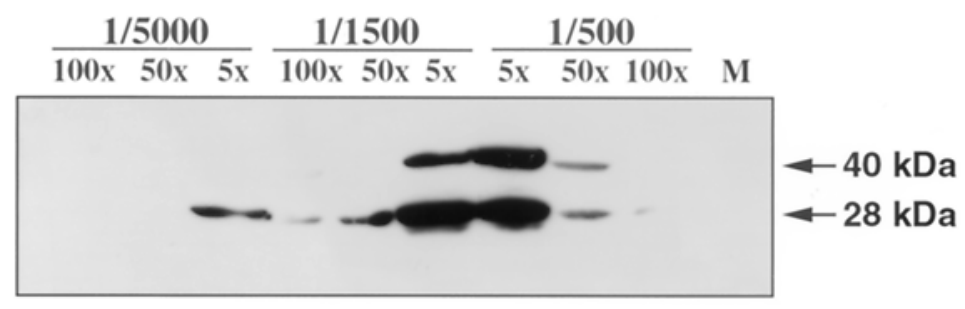

Fig. 2. Sensitivity of Western blot for detection of Rupestris stem pitting associated virus (RSPaV) in grapevines. Lane $\mathrm{M}$ is the BenchMark protein molecular marker. Antiserum to RSPaV (As7-276) was used at dilutions of 1:500, 1:1,500, or 1:5,000. Samples of cambium tissue from dormant canes of Vitis rupestris 'St. George' C1-2-10 were extracted with 5, 50, or 100 volumes of extraction buffer. Donkey anti-rabbit IgG/horseradish peroxidase conjugate was used at a dilution of 1:5,000. The $28-\mathrm{kDa}$ coat protein $(\mathrm{CP})$ of $\mathrm{RSPaV}$ and a $40-\mathrm{kDa}$ protein are indicated by arrows. A $24-\mathrm{kDa}$ protein can be seen just beneath the $\mathrm{CP}$ for the $5 \times$ volumes of extraction buffer at both the 1:500 and 1:1,500 dilutions of antiserum. Top line heading is the antiserum dilution and the line designator beneath that are volumes of buffer used to make plant extract.

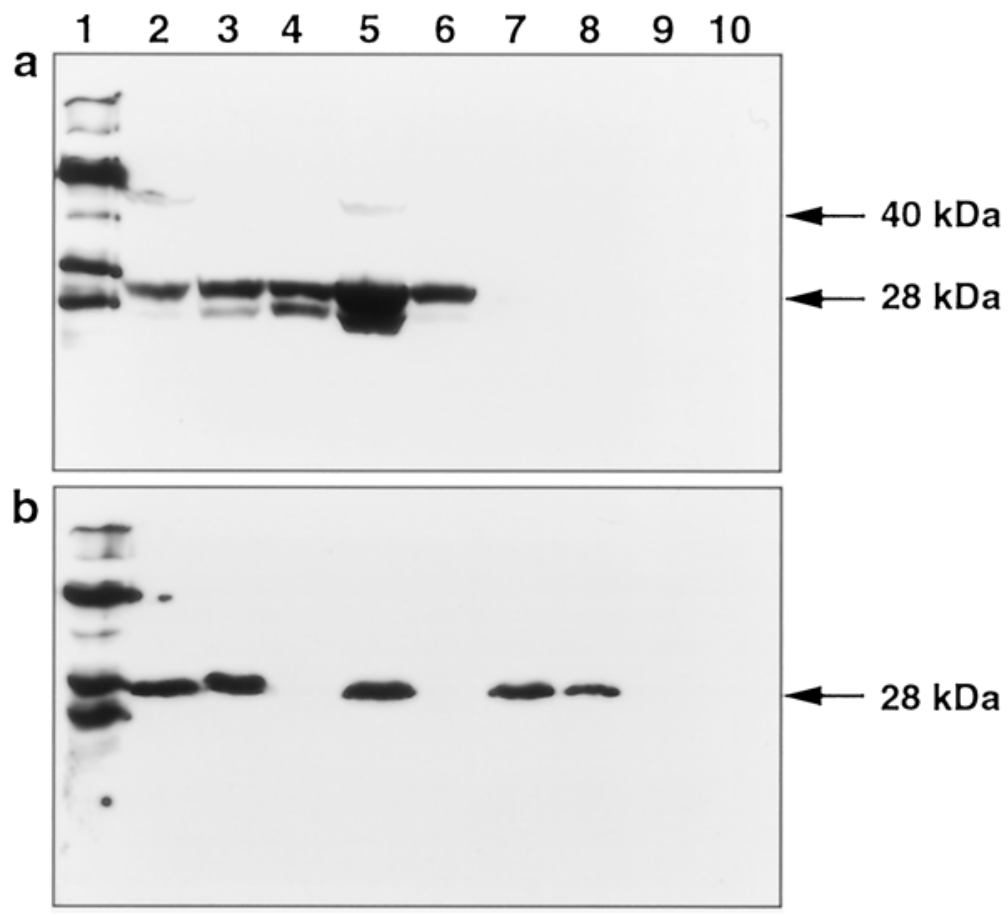

Fig. 3. Detection of Rupestris stem pitting associated virus (RSPaV) in grapevines by Western blot using the antiserum As7-276 to a recombinant coat protein (CP) of RSPaV. A, Cambium of dormant canes was the source of antigen: lane 2, 'Bertille Seyve' 3408; lane 3, 'Bertille Seyve' 5563; lane 4, 'Colobel' 257; lane 5, 'Grande Glabre'; lane 6, 'Ravat' 34; lane 7, 'Seyval'; lane 8, 'Canandaigua'; lane 9, 'Freedom'; and lane 10, 'Dolcetto' DOLC69H (not infected with RSPaV). A smaller protein of ca. $24 \mathrm{kDa}$ was also detected (lanes 2 to 6). 'Seyval' (Panel A, lane 7) showed a very faint band in this test, but the $\mathrm{CP}$ was detected more clearly in repeated Western blot tests. B, Leaves were the source of antigen: lane 2, 'Biancale' BL1; lane 3, 'Canino' CNO15; lane 4, 'Lambrusco' LS3; lane 5, 'Pagadebit' PGD2; lane 6, 'Lambrusco' LGR4A; lane 7, 'Alionza' ALZ1A; lane 8, 'Trebbiano' TR12; lane 9, 'Trebbiano' TR12H; and lane 10, 'Dolcetto' DOLC69H. The recombinant coat protein (300 ng) of RSPaV digested with protease factor Xa to release the $28-\mathrm{kDa}$ coat protein of $\mathrm{RSPaV}$ from the fusion protein, was loaded in lane 1 of both panels. 
Purified As7-276 was more effective than the crude antiserum at detecting $\mathrm{RSPaV}$ from both cambium samples and tissue-cultured plants (Table 4). For example, when cambium tissue was used as the source of antigen, all nine accessions assayed had higher $\mathrm{I} / \mathrm{H}$ ratios when purified antiserum was used than when crude antiserum was used. When crude antiserum was used, none of the accessions had $\mathrm{I} / \mathrm{H}$ values higher than the threshold (Table 4). plants; eight of nine samples had $\mathrm{I} / \mathrm{H}$ ratios higher than the threshold when assayed with purified antiserum (Table 4). Crude antiserum failed to detect the virus in any of the accessions, regardless of whether used as the source of antigen (Table 4). Failure to detect the virus with crude antiserum was due to high background interference, which reached 1.01 for cambium tissue and 0.81 for tissue-cultured plantlets (Table 5). Background values of wells containing buffer only were relatively low, ranging from 0.11 to 0.20 for purified antiserum and from 0.18 to 0.31 for crude antiserum (Table 4).

Additionally, tests were done to determine the effects of antiserum dilution on results of testing RSPaV by ELISA. The results showed that $\mathrm{I} / \mathrm{H}$ values of all samples increased as the dilution increased. Consequently, the number of samples tested positive for RSPaV increased with higher dilutions. For example, at antiserum dilution of 1:1,500, only three of the seven samples infected with $\mathrm{RSPaV}$ had $\mathrm{I} / \mathrm{H}$ The same was true for tissue-cultured cambium or tissue-cultured plantlets were

ratios higher than the threshold; at antiserum dilution of $1: 3,000$, six of the seven samples had $\mathrm{I} / \mathrm{H}$ ratios higher than the threshold; at antiserum dilution of 1:5,000, all seven samples were positive for the virus since the $\mathrm{I} / \mathrm{H}$ ratios were all higher than 2.9 (Table 5). Results at the higher dilution matched those of the Western blot assays. Thus, the optimal condition for the indirect ELISA was to use the antiserum diluted at between 1:3,000 and 1:5,000.

The results from indirect ELISA assays matched nearly perfectly $(97 \%)$ with those of the Western blot and RT-PCR assays (Table 1). RSPaV antigens could be detected from buds and leaves during the growing season, from cambium samples of dormant canes, and from tissue-cultured plantlets. Only $85 \%$ of the plants that tested positive for $\mathrm{RSPaV}$ by indirect ELISA also tested positive by indicator indexing.

Seasonal fluctuation of RSPaV antigen levels in leaves. The $\mathrm{CP}$ antigens of $\mathrm{RSPaV}$ were detected at high levels in samples of 'Seyval' collected on or before 2 September, but levels of RSPaV declined in samples collected on 16 September and 2 October, and RSPaV was not detected in samples collected on 23 October (Fig. 4A). The same trend was observed for samples of 'Bertille Seyve 5563', except that the antigen level declined earlier and could not be detected in samples collected on or after 2 September (Fig. 4B). Furthermore, leaf samples of 'Seyval' appeared to contain higher levels of the RSPaV CP than those of 'Bertille Seyve' 5563 (Fig. 4A and B),

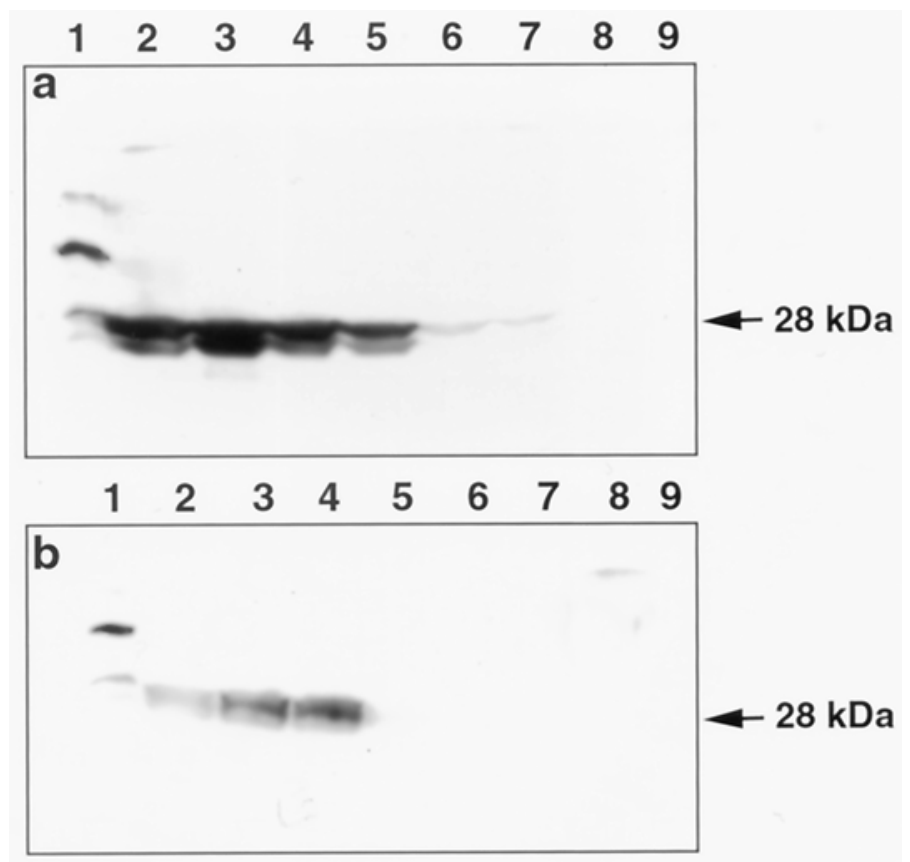

Fig. 4. Western blot showing seasonal decline of Rupestris stem pitting associated virus (RSPaV) in leaves of French-American grapevine hybrids A, 'Seyval' and B, 'Bertille Seyve' 5563. Samples were collected on: lane 2, 19 June; lane 3, 15 July; lane 4, 14 August; lane 5, 2 September; lane 6, 16 September; lane 7, 2 October; and lane 8, 23 October. Lane 9 is the Western blot of Vitis vinifera 'Dolcetto' DOLC69H (not infected with RSPaV). Lane 1 is the recombinant coat protein (300 ng) of $\mathrm{RSPaV}$ digested with Xa to release the coat protein of RSPaV from the fusion protein. indicating that antigen levels differed between the two accessions. This conclusion was based on the observation that, although the same amount of leaf tissue was used in Western blotting, the intensity of protein band from 'Seyval' was much stronger than that from 'Bertille Seyve' 5563 (Fig. 4A and B). Furthermore, among the seven $\mathrm{RSPaV}$-infected grapevine accessions tested in late October, only 'Bertille Seyve' 3408 and 'Lambrusco' LS3 were positive for RSPaV (data not shown).

Detection of RSPaV in ' $\mathrm{St}$. George' indicators. Among the 29 'St. George' plants obtained from two sources (New York and British Columbia) tested in this study, 23 plants were positive for RSPaV, while six were negative for the virus (Table 2). Identical results were obtained for 14 samples tested for RSPaV by both RT-PCR and Western blot (Table 2).

Detection of RSPaV in grapevine seedlings. RSPaV was not detected by Western blotting and ELISA in 19 field-grown grapevine seedlings or in 226 seedling plants originated from seeds of RSPaV-infected 'Seyval' (Table 1; data not shown).

\section{DISCUSSION}

RSP is the most common virus disease of grapevines and occurs worldwide. Of the major virus diseases of grapevines, RSP is the most difficult to diagnose. We have developed a polyclonal antiserum to a recombinant $\mathrm{CP}$ of $\mathrm{RSPaV}$, and demonstrated that the antiserum can be used effectively to detect RSPaV in grapevines by Western blot and indirect ELISA. We have also shown that RSPaV antigen levels in grapevine leaves are high in the summer but become nondetectable later in the season. Furthermore, for the first time, particles of RSPaV have been identified in RSPaV-infected grapevines by immunosorbent electron microscopy using the antiserum (23).

The antiserum As7-276 was effective for detecting $\mathrm{RSPaV}$ in plant extracts diluted up to $1: 100$ by Western blot. The $24-\mathrm{kDa}$ protein detected by Western blot may have resulted from degradation of the $\mathrm{CP}$ during sample processing. Detection of the 40$\mathrm{kDa}$ protein may have been due to a nonspecific reaction of the antiserum with a host protein that was specific to the cambium tissue. The antiserum was also effective in detecting RSPaV by indirect ELISA when the following conditions were met: (i) the antiserum was purified or crude antiserum was diluted at least 1:3,000; (ii) dormant canes were used; and (iii) leaf samples collected during the actively growing season were tested. In addition, preliminary data indicate that crossabsorption of the antiserum with extract from healthy grapevines could further improve the performance of the antiserum (B. Meng, unpublished data).

Serological and RT-PCR methods are advantageous compared with classical 
indicator indexing for the following reasons. Indicator indexing takes 2 to 3 years to complete and is labor-intensive. In contrast, serological and RT-PCR assays can be completed within a couple of days. Since these assays can be used to test for a large number of samples at the same time, cost will be substantially reduced.

For surveying large numbers of samples, ELISA could be used first to screen for samples heavily infected with the virus. Samples for which results by ELISA were uncertain should be re-tested by Western blot and/or RT-PCR assays. For RT-PCR assays, broad-spectrum primers such as primers 13 and 14 , and 21 and 22 are recommended because they are capable of detecting a wide range of sequence variants of RSPaV (18). Also, simplified RNA isolation methods should be used to obtain templates efficiently (27).

$\mathrm{RSPaV}$ antigen levels in grapevine leaves appear to fluctuate with time. $\mathrm{RSPaV}$ antigens were detected at high levels in grapevine leaves collected in the summer but became nondetectable afterwards. The time at which $\mathrm{RSPaV}$ antigen levels began to decrease coincided with the cessation in vegetative growth of the plants, i.e., in late August for cropped grapevines in New York (4). Thus, to ensure detection of the virus, we recommend that leaves be sampled when plants are still actively growing. These results differed slightly from those of Minafra et al. (19), who observed that RSPaV antigen levels remained constant from June to October. This may reflect differences in climate between regions of this study and the one carried out by Minafra et al. (19).

A majority of the 'St. George' plants assayed, despite the fact that 'St. George' has been used worldwide as the standard indicator for RSP for nearly three decades, were positive for RSPaV based on extensive testing of 'St. George' plants from two sources by Western blot and RT-PCR. These results support those of Minafra et al. (19), who detected RSPaV in 16 of 20 wild plants of $V$. rupestris and in the 'St. George' selection used as the indicator in the certification program at Bari, Italy. The implications of this finding in relation to past uses of the indicator indexing remain puzzling. Recent sequence data (17; B. Meng, unpublished data) show that the $\mathrm{RSPaV}$ isolate found in plants of 'St. George' is homogeneous in genome composition but differs from the isolate sequenced previously (17). However, previous indicator indexing results provide no evidence that the isolate of RSPaV found in 'St. George' plants produces RSP symptoms on nongrafted or self-grafted plants of 'St. George'. Thus, we hypothesize that this new isolate is a latent strain of the virus. In addition, several 'St. George' plants from fields or derived from somatic embryogenic culture $(15,24)$ have been identified as free of RSPaV and may serve as a source of 'clean' indicator plants for future use.

Minafra et al. (19) also produced an antiserum to a recombinant $\mathrm{CP}$ of $\mathrm{RSPaV}$, which was effective for detecting RSPaV by Western blot but not by ELISA. In contrast, the antiserum As7-276 was effective for detecting RSPaV not only by Western blot, but also by indirect ELISA and immunosorbent electron microscopy (23). Differences between these two antisera may be due to the amount of immunogens used to develop the antisera. For example, Minafra et al. (19) injected a rabbit with $900 \mathrm{mg}$ of the recombinant protein, whereas $0.6 \mathrm{mg}$ of the recombinant protein was used in this study.

The genome structure of RSPaV suggests the virus has similar morphology to potexviruses (17). Although filamentous virus aggregates have been observed from grapevines infected with RSP (28) or with RSP and LNSG (20), the relationship of these virus particles to $\mathrm{RSPaV}$ was not determined because of the lack of RSPaVspecific antiserum. Recently, for the first time, we identified particles of RSPaV, with the predicted morphology and length, by electron microscopy using As7-276 to trap and decorate the virus particles (23).

Plants of $V$. vinifera 'Lambrusco' LGR4A, although infected with RSP and KSG based on biological indexing on indictors (3), were negative for RSPaV by Western blot, indirect ELISA, and RT-PCR (Table 1). This suggests a virus distinct from RSPaV may be responsible for the symptoms elicited on the indicator 'St. George'. Alternatively, symptoms induced by this accession on 'St. George' might have been caused by more than one virus, as Grapevine leafroll associated virus-1 and GVA were also detected in this grapevine accession (3).

Preliminary data suggest that RSPaV is not transmitted through embryos. RSPaV was not detected in any of the field-grown seedlings or the seedling plants originated from RSPaV-infected plants of 'Seyval' by Western blot and ELISA, when using As7276. Similar results were reported by $\mathrm{Mi}$ nafra et al. (19). Stewart and Nassuth (27), however, detected RSPaV by RT-PCR of seeds from several RSPaV-infected cultivars of $V$. vinifera, even after treatment of the seeds with bleach. Additional studies are needed to determine the potential for $\mathrm{RSPaV}$ to be seedborne.

Antibodies to recombinant viral CPs expressed in bacterial cells have been explored for detecting plant viruses (810,21,25,29). Except for Tomato spotted wilt virus and Grapevine leafroll associated virus-3, the antibodies were only effective by indirect ELISA. Similarly, our data demonstrate that As7-276 was effective for detecting RSPaV by indirect, but not by direct ELISA, as ELISA wells containing buffer or extracts from RSPaV-free samples produced OD values comparable to those of wells containing extracts from RSPaV-infected samples (B. Meng, unpublished data). Presence of the MBP, which accounts for $60 \%$ of the fusion protein, may have changed the three-dimensional structure and the antigenic property of the CP. Separation of the CP from the MBP, and production of antibodies to the cleaved $\mathrm{CP}$, may improve performance of the antiserum in ELISA.

RSP represents a diverse group of viral diseases of woody plants, including the RW disease complex of grapevines. Common characteristics of the diseases include unknown and complex etiologies, difficulties in isolation of viruses due to low virus titer and inhibitory components in the hosts, and inability to transfer the viruses to herbaceous hosts. The strategy we have developed to study RSP, from sequencing the genome of the associated virus to validating the relationship between the viral sequence and symptoms of the disease, provides a model system for unraveling disease complexes of uncertain etiology on woody plants.

\section{ACKNOWLEDGMENTS}

This work is supported in part by the USDA/ARS cooperative agreement no. 58-19084-023 with the USDA Plant Genetic Resources Unit at Geneva, NY. We thank G. Mittak, S. Day, $\mathrm{X}$. $\mathrm{Xu}$, and $\mathrm{F}$. Penev for technical assistance.

\section{LITERATURE CITED}

1. Azzam, O. I., Gonsalves, D., and Golino, D. A. 1991. Detection of dsRNA in grapevines showing symptoms of Rupestris stem pitting disease and the variabilities encountered. Plant Dis. 75:960-964.

2. Clark, M. F. 1981. Immunosorbent assays in plant pathology. Annu. Rev. Phytopathol. 19:83-106.

3. Credi, R. 1997. Characterization of grapevine rugose wood disease sources from Italy. Plant Dis. 81:1288-1292.

4. Goffinet, M. 1991. Buds and shoots of grapevines. Grape Research News. Vol. 2, No. 2:13. New York State Agricultural Experiment Station, Geneva.

5. Goheen, A. C. 1988. Rupestris stem pitting. Page 53 in: R. C. Pearson and A. C. Goheen, eds. Compendium of Grape Diseases. American Phytopathological Society, St. Paul, MN.

6. Goheen, A. C. 1989. Virus diseases and grapevine selection. Am. J. Enol. Vitic. 40:6772.

7. Habili, N., Bonfiglioli, R., and Symons, R. 1998. Rupestris stem pitting associated virus in Australia - Does it pose a threat to the viticultural industry? Austral. Grapegr. Winemaker 417:38-39.

8. Jelkmann, W., and Keim-Konrad, R. 1997. Immuno-capture polymerase chain reaction and plate-trapping ELISA for the detection of apple stem pitting virus. J. Phytopathol. 145:499-503.

9. Kaden-Kreuziger, D., Lamprecht, S., Martin, R. R., and Jelkmann, W. 1995. Immunocapture polymerase chain reaction assay and ELISA for the detection of strawberry mild yellow edge associated potexvirus. Acta Hortic. 385:33-40.

10. Ling, K.-S., Zhu, H.-Y., Jiang, Z.-Y., and Gonsalves, D. 2000. Effective application of DAS-ELISA for detection of grapevine leafroll associated closterovirus-3 using a polyclonal antiserum developed from recombinant 
coat protein. Eur. J. Plant Pathol. 106:301309.

11. Martelli, G. P. 1993. Rugose wood complex. Pages 45-54 in: Graft-Transmissible Diseases of Grapevines: Handbook for Detection and Diagnosis. G. P. Martelli, ed. Food and Agriculture Organization of the United Nations, Rome, Italy.

12. Martelli, G. P., and Jelkmann, W. 1998. Foveavirus, a new plant virus genus. Arch. Virol. 143:1245-1249.

13. Meng, B., Credi, R., Petrovic, N., and Gonsalves, D. 2000. Serological detection of $\mathrm{RSPaV}$ in grapes as compared to RT-PCR and indicator indexing. Pages 131-132 in: Extended Abstr. Meeting Int. Council Study Viruses Virus-like Dis. Grapevine, 13th. Adelaide, South Australia.

14. Meng, B., and Gonsalves, D. 1997. Nucleotide sequence and genomic organization of grapevine Rupestris stem pitting-associated virus and its detection by RT-PCR. (Abstr.) Phytopathology 87:S65.

15. Meng, B., Goszczynski, D. E., and Gonsalves, D. 2000. Detection of rupestris stem pitting associated virus-1 in the indicator Vitis rupestris St. George and sequence analysis. Pages 43-44 in: Proc. Meeting Int. Council Study Viruses Virus-like Dis. Grapevine, 13th. Adelaide, South Australia.

16. Meng, B., Johnson, R., Peressini, S., Forsline, P. L., and Gonsalves, D. 1999. RSPaV-1 is consistently detected in rupestris stem pittinginfected grapevines. Eur. J. Plant Pathol. 105:191-199.

17. Meng, B., Pang, S. Z., Forsline, P. L., McFerson, J. R., and Gonsalves, D. 1998. Nucleo- tide sequence and genome structure of grapevine rupestris stem pitting associated virus-1 reveal similarities to apple stem pitting virus. J. Gen. Virol. 79:2059-2069.

18. Meng, B., Zhu, H. Y., and Gonsalves, D. 1999. Rupestris stem pitting associated virus1 consists of a family of sequence variants. Arch. Virol. 144:2071-2085.

19. Minafra, A., Casati, P., Elicio, V., Rowhani, A., Saldarelli, P., Savino, V., and Martelli, P. 2000. Serological detection of grapevine rupestris stem pitting-associated virus (GRSPaV) by a polyclonal antiserum to recombinant virus coat protein. Vitis 39:115118.

20. Monette, P. L., and Godkin, S. E. 1995. Detection of capillovirus-like particles in a grapevine affected with rugose wood. Vitis 34:241-242.

21. Nikolaeva, O. V., Karasev, A. V., Gumpf, D. J., Lee, R. F., and Garnsey, S. M. 1995. Production of polyclonal antisera to the coat protein of citrus tristeza virus expressed in Escherichia coli: Application for immunodiagnosis. Phytopathology 85:691-694.

22. Nolasco, G., Mansinho, A., Teixeira Santos, M., Soares, C., Sequeira, Z., Sequeira, C., Correia, P. K., and Sequeira, O. A. 2000. Large scale evaluation of primers for diagnosis of rupestris stem pitting associated virus1. Eur. J. Plant Pathol. 106:311-318.

23. Petrovic, N., Meng, B., Ravnikar, M., Mavric, I., and Gonsalves, D. 2003. First detection of Rupestris stem pitting associated virus particles in grapevine by antibody to a recombinant coat protein. Plant Dis. 87:510-514.

24. Petrovic, N., Penev, B., Krastanova, T., Meng,
B., and Gonsalves, D. 2000. Distribution of Rupestris stem pitting associated virus in greenhouse and field grown Vitis rupestris $\mathrm{St}$ George. Pages 35-36 in: Meeting Int. Council Study Viruses Virus like Dis. Grapevin, 13th. Adelaide, South Australia.

25. Quail, A. M., Martin, R. R., Jelkmann, W. and Spiegel, S. 1995. Development of monoclonal antibodies specific for strawberry mild yellow edge potexvirus. Acta Hortic. 385:3945

26. Sambrook, J., Fritsch, E. F., and Maniatis, T. 1989. Molecular Cloning: A Laboratory Manual, 2nd ed. Cold Spring Harbor Laboratory Press, Cold Spring Harbor, NY.

27. Stewart, S., and Nassuth, A. 2001. RT-PCR based detection of Rupestris stem pitting associated virus within field-grown grapevines throughout the year. Plant Dis. 85:617-620.

28. Tzeng, H. L., Tzeng, D. D., and Goheen, A. C. 1993. Anatomical and tissue culture studies of rupestris stem pitting-affected grapevines. Bot. Bull. Acad. Sinica (Taipei) 34:73-82.

29. Vaira, A. M., Vecchiati, M., Masenga, V., and Accotto, G. P. 1996. A polyclonal antiserum gainst a recombinant viral protein combines specificity with versatility. J. Virol. Methods 56:209-219.

30. Walter, M. H., and Cameron, H. R. 1991. Double-stranded RNA isolated from grapevines affected by rupestris stem pitting disease. Am. J. Enol. Vitic. 42:175-179.

31. Zhang, Y.-P., Uyemoto, J. K., Golino, D. A., and Rowhani, A. 1998. Nucleotide sequence and RT-PCR detection of a virus associated with grapevine rupestris stem-pitting disease. Phytopathology 88:1231-1237. 